\title{
MEASURING MECHANICAL RESISTANCES OF A HEAVY GOOD VEHICLE BY COASTDOWN TEST
}

\author{
Tomáš Skrúcaný', Štefánia Semanová', Martin Kendra', Tomasz Figlus², Ján Vrábel'
}

1 University of Žilina, Faculty of Operation and Economics of Transport and Communications, Univerzitná 1, 010 26, Žilina, Slovak Republic, e-mail: tomas.skrucany@fpedas.uniza.sk, stefania.semanova@fpedas.uniza. sk, martin.kendra@fpedas.uniza.sk, jan.vrabel@fpedas.uniza.sk

2 Silesian University of Technology, Faculty of Transport, 8 Krasinskiego Street, 40-019, Katowice, Poland, e-mail: tomasz.figlus@polsl.pl

Received: 2018.04.20

Accepted: 2018.05.16 Published: 2018.06.01

\begin{abstract}
Mechanical resistance consists of rolling tire resistance and power losses of vehicle drive train. Rolling resistance is done by deformation of vehicle tires on road surface. Power losses represent resistances of bearings and wheels rolling and oil wading. This resistance acts continuously during vehicle wheels rotation. The value of this driving resistance is possible to test by different methods. Laboratory tests on rotating drum or dynamometer are usually used. This paper deals about rare method - coastdown exterior driving test. It was done with a casual truck trailer set. Results of this test method show the value of this resistance forces which are converted into a coefficient of mechanical resistance and discussed in the point of view of rolling resistance coefficient values.
\end{abstract}

Keywords: mechanical resistance, rolling resistance, coastdown test, heavy good vehicle.

\section{INTRODUCTION}

Transportation of goods is constantly growing in the EU and we have to look up how to develop further freight transport which would match the demand for transport and integrate all modes of transport into the system which is the most environmentally friendly and sustainable for the future $[1,2,4]$. One option is the use of vehicles with the lower energy consumption which reduce the negative impact of the traffic on the environment and reduce the costs for the transport operator as well $[3,5$, $12,25]$. Energy consumption directly dependents i.a. on technical characteristics of the vehicle during the driving.

Various forces act against the vehicle movement. Because they create resistance against the movement, they are called resistance forc- es $[13,16,20,27]$. Their size is dependent on the instantaneous physical properties of the environment in which a vehicle moves, also the technical construction of the vehicle and its parts $[8,15,19]$. These forces represent particularly air resistance, gradient resistance, inertia resistance, rolling resistance, and losses in the vehicle powertrain. Rolling resistance and losses in the vehicle powertrain are together denoted as mechanical resistance of the vehicle $[9,11]$.

The methods to ascertain the mechanical resistance can be divided into two groups:

- tests on stationary device,

- driving tests (coastdown tests).

Determining mechanical resistance forces correctly will help to find weak points in the technical structure of the vehicles. 


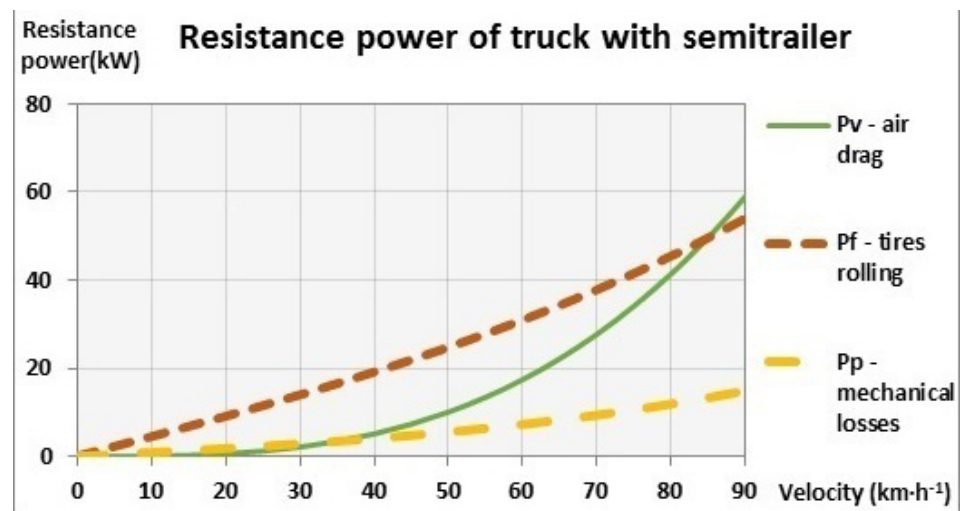

Fig. 1. Resistance power of moving truck [23]

\section{STANDARD STN 30 0554: ROAD MOTOR VEHICLES. COASTDOWN TEST OF ROAD MOTOR VEHICLES}

Coastdown tests are the exterior tests carried out on vehicles in real conditions. The procedure for coastdown tests, weather conditions and conditions related to recording devices are described in various standards. Standard STN 300554 applies in the Slovak Republic.

The principal of coastdown tests is that a vehicle running by inertia is slowed down due to the effect of driving resistances from the moment of shifting neutral position of the transmission device until the moment of reaching the final speed. The test is carried out on the test track. During the test, the instantaneous vehicle speed in dependence on time is ascertained (vehicle deceleration is measured). Based on the equation of motion and detection of instantaneous properties of the environment, it is possible to determine the resultant resistance forces acting on the vehicle and their changes in terms of vehicle speed. Depending on the size of these forces, it is further possible to determine the operating parameters of the vehicle such as coefficient of drag, coefficient of rolling resistance and etc [10, 24].

\section{METHODOLOGY OF COASTDOWN TEST}

The standard applies for determination of driving resistance of a vehicle depending on its speed for passenger cars, freight vehicles, buses and vehicles with trailers and semitrailers. On contrary, the standard is not valid for single-track vehicles, agricultural machinery and tractors. Coastdown characteristic of vehicles is ascertained by this test. Based on this characteristic, it is possible to assess the mechanical condition of the vehicle, chassis settings, the impact of used tyres, and aerodynamic properties of the vehicle body $[6,7]$.

Vehicle movement is straightforward and unevenly decelerated during the coastdown test.

Driving resistances are calculated based on the ascertained course of vehicle deceleration, geometric properties of the measuring section, and parameters of vehicle inertia. Measured driving resistance of the vehicle and the coastdown characteristics are determined by a calculation $[17,18]$. When performing a coastdown test, the set requirements related to the vehicle, test track, test speed, atmospheric conditions and measuring tools must be met.

\section{TEST TRACK}

The coastdown test is carried out on a cement or asphalt road which provides a sufficiently long measuring section with a quality hard road surface. The measuring section must be windprotected against the cross wind so that properties of this protection remain unchanged along the whole section. At both ends of the measuring section, there have to be additional sections of such a length and surface which enables to reliably achieve the required speed and to safely stop the vehicle after passing the measuring section. It is necessary to clearly mark the beginning and the end of the measuring section before carrying out the test. A disruptive impact of other vehicles shall be limited as much as possible during the test. The measuring section must be straight, at least 1000 metres long with quality surface and as wide as possible. A longitudinal slope is permitted, but it may not exceed $1 \%$ and a cross slope may not exceed $1.5 \%$. 


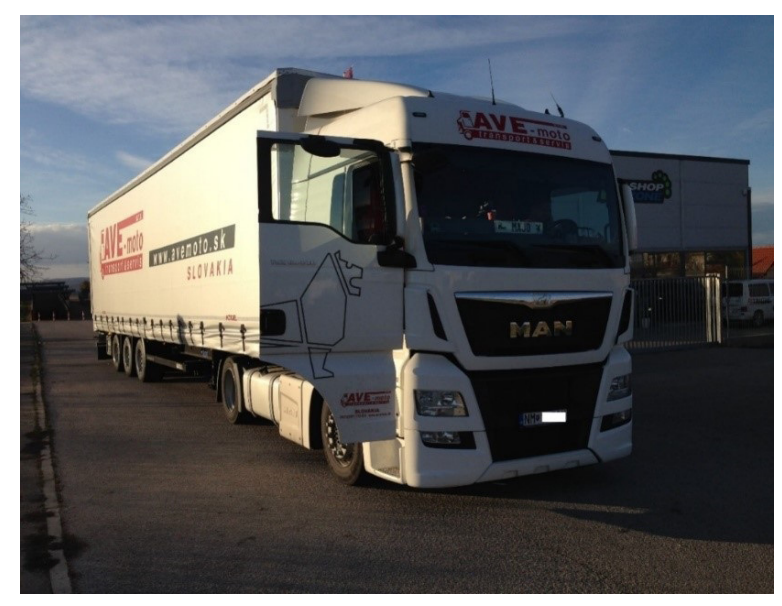

Fig. 2. Examinated vehicle

Atmospheric conditions must be in the following range during the measurement:

- air temperature: $5-25^{\circ} \mathrm{C}$,

- air pressure: $97.33-101.25 \mathrm{kPa}$,

- wind strength up to $1.5 \mathrm{~m} \cdot \mathrm{s}^{-1}$.

\section{MEASUREMENT PROCEDURE}

A vehicle sets off on a test track so that it achieves about $3-5 \%$ higher speed as the test speed when shifting into neutral about 50 metres before the beginning of the measuring section. Before the measuring section, recording device is turned on and the crossing of the beginning of the measuring section is recorded. The vehicle moves by its own inertia (with the engine idling) through the measuring section. Vehicle movement must be smooth without any sudden changes in direction and without movement of passengers. When the vehicle stops in the measuring section, the recording device is turned off. When the vehicle does not stop within the measuring section, the end of the measuring section is indicated on the recording device and then it is turned off. Subsequently, the next measurement is carried out in the same direction and at initial speed which is about $10 \mathrm{~km} \cdot \mathrm{h}^{-1}$ higher than the speed measured at the end of the measuring section during the previous measurement. Measurements are repeatedly performed in this manner until the vehicle stops within the measuring section.

\section{OWN MEASUREMENT OF COASTDOWN}

To ensure the required outputs of the sufficient explanatory power, we compiled own methodology for carrying out the coastdown test tak- ing into account the conditions and principles of the mentioned STN standard.

The measurement was carried out by using a semi-trailer truck. The chosen tested tractor unit was MAN TGX 18.444. The total weight of the vehicle is 40 tonnes, however, the instantaneous weight of the empty vehicle was 15.1 tonnes during the test.

\section{MEASURING EQUIPMENT}

For the purpose of the coastdown test, we needed to ensure appropriate measuring equipment for recording the coastdown characteristics as well as the controlling device for measuring the ambient operational and weather conditions. The used measuring equipment consisted of:

- tablet with GPS device,

- anemometer,

- thermometer of tyres,

- weather station,

- tyre barometer.

\section{GPS DEVICE}

To determine the coastdown characteristics, we needed a GPS device by using which we could measure the required variables. Tablet Dell Venue 7 with integrated GPS 3G Module was used for the measurement. To interpret results and export them to Microsoft Excel, we had to firstly install Android Speedometer which can export necessary data to Microsoft Excel. It also provides further functions, such as display of the elevation profile, speed profile and display of measured track.

\section{ANEMOMETER}

A handheld anemometer was used to measure wind speed. This anemometer allows to measure only wind speed. For this purpose, the device consists of rotating parts with the cross on the arms of which there is a rotor with vanes. Wind speed is proportional to the number of turns of rotating parts of the device per a time unit. It is possible to determine average values of wind speed based on the number of turns.

\section{CONTACT THERMOMETER}

We used a contact thermometer to check the temperature of tyres. After placing the thermometer on the tyre surface, we ascertained values from the digital display before and after the coastdown test. This support measurement was done for se- 


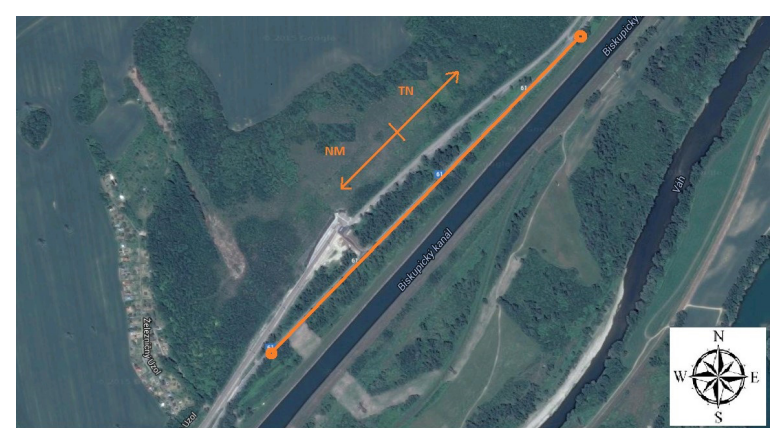

Fig. 3. The test track for the coastdown measurement

curing the same athmospheric conditions during the whole coastdown test.

\section{TEST TRACK FOR MEASUREMENT}

Coastdown tests were carried out in the section of first class road No. I/61 between towns Nové Mesto nad Váhom (NM) and Trenčín (TN). The chosen road section is suitable in terms of quality road surface and it has sufficient length for carrying out the coastdown test. It also provides possibility for additional sections needed to achieve the required initial speed and safe stop of the vehicle. This road section meets the requirements set by the STN standard.

\section{MEASUREMENT PROCEDURE}

The measurement procedure is based on the principles of the standard. However, we slightly adjusted the procedure according to the requirements of own measurement and used equipment. At the beginning, we ascertained operational conditions of the vehicle and atmospheric conditions (air temperature and pressure). We also measured tyre pressure and tyre temperature. The GPS device was installed into vehicle. The vehicle was warmed up to operating temperature prior to carrying out the coastdown test. We made sure that all windows were closed and holes for the air supply to the engine were transitional. We launched the vehicle on the test track to achieve initial speed for the coastdown measurement. Then, we shifted into neutral at the beginning of the measuring section and at the same time we turned on the recording device. The vehicle moved by its own inertia with the engine idling and then it stopped within the measuring section and the recording device was turned off at the same time. Subsequently, we carried out further measurements.
To determine the rolling resistance of the vehicle, it is necessary to know input data. Some of them, such as weight of the wheel and brake disc, were known. However, others had to be expressed by using formulas of known parameters, e.g. efficiency of the transmission system and coefficient $\delta$.

For the vehicle, it is necessary to find out efficiency in the transmission system and torque of inertia of the rotating masses for axles of a tractor unit and axles of a semi-trailer.

$$
0=\left(o_{f}+o_{X}\right)+o_{V}-o_{a}
$$

where: $\mathrm{o}_{\mathrm{f}}$ - specific rolling resistance $\left(\mathrm{N} \cdot \mathrm{N}^{-1}\right)$

$\mathrm{o}_{\mathrm{X}}-$ specific resistance of vehicle powertrain $\left(\mathrm{N} \cdot \mathrm{N}^{-1}\right)$

$\mathrm{o}_{\mathrm{V}}-$ specific air resistance $\left(\mathrm{N} \cdot \mathrm{N}^{-1}\right)$

$\mathrm{O}_{\mathrm{a}}-$ specific resistance of inertia $\left(\mathrm{N} \cdot \mathrm{N}^{-1}\right)$

Based on the equation of motion of specific resistances (equation 1), it is obvious that various driving resistances act on the vehicle at the same time. If we want to determine reliably the mechanical resistance by using the coastdown test, it is necessary to eliminate the effects of the remaining resistances. This can be achieved by carrying out the test at low initial speed of coastdown (elimination of air resistance) and on the test track which is as horizontal as possible (elimination of gradient resistance). Therefore, the coastdown test was carried out from the initial speed of $15 \mathrm{~km} \cdot \mathrm{h}^{-1}$ till the vehicle stop. At such speed, the air resistance is very low, close to 0 and this represents negligible value in comparison with mechanical resistance. The mechanical resistance represents rolling resistance together with losses in the vehicle powertrain and it is denoted as $\mathrm{o}_{\mathrm{M}}$.

$$
\begin{aligned}
& 0=o_{M}-o_{a} \\
& 0=\frac{f}{\eta}-\frac{a}{g} \times \delta \\
& f=\frac{b \times \delta \times \eta}{g}
\end{aligned}
$$

where: $\mathrm{o}_{\mathrm{M}}$ - specific mechanical resistance $\left(\mathrm{N} \cdot \mathrm{N}^{-1}\right)$ $\eta$ - efficiency of the powertrain $\left(\mathrm{N} \cdot \mathrm{N}^{-1}\right)$ $\mathrm{f}$ - coefficient of rolling resistance $\left(\mathrm{N}^{-} \mathrm{N}^{-1}\right)$ $\mathrm{a}, \mathrm{b}$ - vehicle acceleration $(\mathrm{a}=\mathrm{-b}=$ deceleration) $\left(\mathrm{m} \cdot \mathrm{s}^{-2}\right)$

$\delta$ - coefficient of inertia of rotating masses (-) $\mathrm{g}$ - gravity acceleration $\left(\mathrm{m} \cdot \mathrm{s}^{-2}\right)$ 


\section{CALCULATION OF EFFICIENCY IN THE TRANSMISSION SYSTEM}

To calculate efficiency in the transmission system, we took into account the normal values of partial losses in individual parts of the transmission system and we chose the average values [21, 22]. In case of the combination vehicle consisting of the tractor unit with the semi-trailer, the losses in the transmission system and in the wheel bearings represents $\eta=0.947$.

\section{CALCULATION OF COEFFICIENT OF ROTATING MASSES INERTIA - $\Delta$}

The coefficient of inertia of rotating masses $\delta$ is important for the calculation of the coefficient of rolling resistance.

$$
\delta=1+\frac{\sum I}{m_{v} \times r_{d}{ }^{2}}
$$

where: $\sum \mathrm{I}$ - the sum of torques of inertia of wheels on individual axles $\left(\mathrm{kg} \cdot \mathrm{m}^{2}\right)$

$\mathrm{m}_{\mathrm{v}}$ - vehicle weight $(\mathrm{kg})$

$r_{d}-$ dynamic radius of the wheel $(m)$

\section{PROCEDURE FOR MEASUREMENT EVALUATION}

The data measured by using the GPS device (tablet) with installed software Android Speedometer were exported to Microsoft Excel. Subsequently, we adjusted the obtained data to be further processed. Based on the coastdown characteristics, we constructed a graph which depicts deceleration. Due to slight inaccuracies of the GPS device we added a trend line. By using a logarith- mic equation (compiled by Excel) we were able to smooth out the curve of decreasing speed of the vehicle during deceleration. Then, we could calculate the braking deceleration depending on time. The required data were substituted into the formula to calculate the coefficient of rolling resistance. This resulted in determination of coefficient of rolling resistance for each driving and coefficient of rolling resistance of the vehicle including losses in the vehicle transmission system.

\section{A SAMPLE GRAPH OF SPEED DEPENDING ON TIME}

By using a trend line with the polynomial function it was possible to smooth out the curve of speed. The equation is shown in the graph. This course of speed was then used for further calculations.

\section{THE FINAL TABLE WITH THE CALCULATED VALUES OF COEFFICIENTS}

This chapter shows the final evaluated results. Numbers in tables represent the values of mechanical and rolling coefficients estimated by coastdown test.

Table 1 presents the values of rolling coefficient. The measured values are in the scale from 5.1 to 6.5 . This range is caused by changing wind velocity and direction during measurement and also by the measurement direction (TN or NM). Average value for the direction $\mathrm{TN}$ is 6.15 (uphill) and for NM 5.45 (downhill). The average slope of the test track is only $0.155 \%$ (standard allows $1 \%$ ) but this slope with the mixture of the wind caused these differences between each measurements. The final value of the measured rolling coefficient is 5.8. This

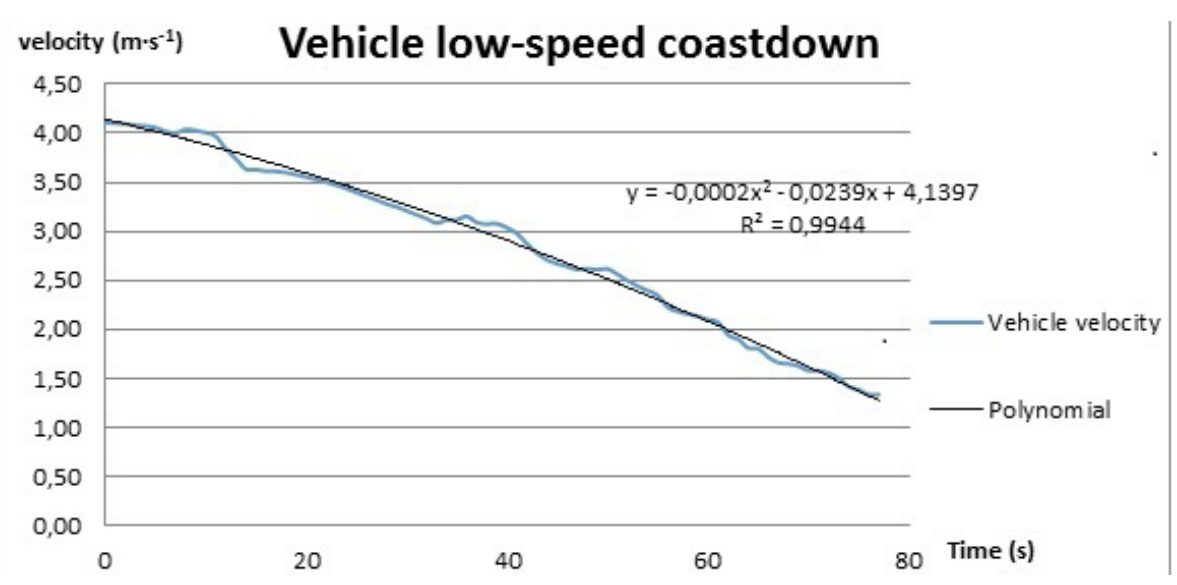

Fig. 4. Vehicle coastdown 
Table 1. Final values of rolling coefficient

\begin{tabular}{|c|c|c|c|c|c|c|c|}
\hline Direction & $\begin{array}{c}f \cdot 10^{-3} \\
(-)\end{array}$ & $\begin{array}{l}\text { Average: one } \\
\text { direction }\end{array}$ & $\begin{array}{r}\text { Overall } \\
\text { average }\end{array}$ & $\begin{array}{l}\text { Standard } \\
\text { deviation }\end{array}$ & $\begin{array}{l}\text { Reliability of polynomial } \\
\text { function }\end{array}$ & $\begin{array}{l}\text { Average of } \\
\text { reliability }\end{array}$ & $\begin{array}{l}\text { Wind } \\
\left(m \cdot s^{-1}\right)\end{array}$ \\
\hline $\mathrm{TN}$ & 6.5 & \multirow{2}{*}{6.5} & \multirow{8}{*}{5.8} & \multirow{8}{*}{$0.6 \cdot 10^{-3}$} & 0.73 & \multirow{8}{*}{0.84} & 0.58 \\
\hline $\mathrm{TN}$ & 6.5 & & & & 0.893 & & 1.00 \\
\hline NM & 5.2 & \multirow{2}{*}{5.5} & & & 0.89 & & 1.25 \\
\hline NM & 5.7 & & & & 0.86 & & 2.17 \\
\hline $\mathrm{TN}$ & 5.2 & \multirow{2}{*}{5.8} & & & 0.71 & & 0.50 \\
\hline $\mathrm{TN}$ & 6.3 & & & & 0.88 & & 2.00 \\
\hline NM & 5.7 & \multirow{2}{*}{5.4} & & & 0.84 & & - \\
\hline NM & 5.1 & & & & 0.91 & & - \\
\hline
\end{tabular}

Table 2. Final values of mechanical coefficient

\begin{tabular}{|c|c|c|c|c|c|c|c|}
\hline Direction & $\begin{array}{c}m \cdot 10^{-3} \\
(-)\end{array}$ & $\begin{array}{l}\text { Average: one } \\
\text { direction }\end{array}$ & $\begin{array}{l}\text { Overall } \\
\text { average }\end{array}$ & $\begin{array}{l}\text { Standard } \\
\text { deviation }\end{array}$ & $\begin{array}{l}\text { Reliability of polynomial } \\
\text { function }\end{array}$ & $\begin{array}{l}\text { Average of } \\
\text { reliability }\end{array}$ & $\begin{array}{l}\text { Wind } \\
\left(\mathrm{m} \cdot \mathrm{s}^{-1}\right)\end{array}$ \\
\hline $\mathrm{TN}$ & 6.8 & \multirow{2}{*}{6.8} & \multirow{8}{*}{6.0} & \multirow{8}{*}{$0.6 \cdot 10^{-3}$} & 0.73 & \multirow{8}{*}{0.84} & 0.58 \\
\hline $\mathrm{TN}$ & 6.8 & & & & 0.893 & & 1.00 \\
\hline NM & 5.4 & \multirow{2}{*}{5.7} & & & 0.89 & & 1.25 \\
\hline NM & 5.9 & & & & 0.86 & & 2.17 \\
\hline TN & 5.4 & \multirow{2}{*}{6.0} & & & 0.71 & & 0.50 \\
\hline $\mathrm{TN}$ & 6.5 & & & & 0.88 & & 2.00 \\
\hline NM & 5.9 & \multirow{2}{*}{5.6} & & & 0.84 & & - \\
\hline NM & 5.3 & & & & 0.91 & & - \\
\hline
\end{tabular}

value is similar to the official producer value for used vehicle tires which is 0.55 (mixture of tires and actual axle load and producer coefficient value).

Table 2 shows the results of mechanical losses, exactly coefficient of mechanical losses. As written above, the mechanical resistance represents rolling resistance together with losses in the vehicle powertrain. There is $\mathrm{O}_{\mathrm{M}}$ what can be written also as $\mathrm{m}$ (tab. 2), explained in equation 2 and there is its following physical disposition in equations 3 . The mechanical coefficient $\mathrm{m}$ is a share of the rolling coefficient and the power train efficiency $\eta(f / \eta)$. The value of powertrain efficiency (0.947) was calculated according to the technical construction of the power train and the losses of each mechanical part in the train. The average value represents the value of rolling coefficient $(0.58)$ decreased by the power train efficiency. The final result is 0.6 , what represents the coefficient of mechanical resistance of moving truck by low velocity. This value increases with increasing the vehicle speed.

\section{CONCLUSIONS}

Driving resistances acting during the vehicle motion play an important role in the vehicle effi- ciency. With increasing of these resistances overall vehicle efficiency is decreasing because more fuel has to be burnt for the same move (transport power) $[13,14,26]$. One part of driving resistances - mechanical resistance was investigated in this paper. This mechanical resistance is built from two other losses - rolling resistance and mechanical power train losses - is acting for all the time when the vehicle is moving. This paper evaluated value of this resistance by coastdown test performing. This test - carried out in low speed part of the coastdown - gave results in a form of coastdown curve (velocity and time functionality). From these results it is able to calculate vehicle actual deceleration and also the actual resistances. The measured and calculated values of rolling coefficient are very similar to the declared value by tire producer. This sort of coastdown tests are very useful for determining the real value of vehicle driving resistances and its reliability can be increased by making some support test e.g. constant speed fuel consumption test.

\section{ACKNOWLEDGEMENT}

Project Centre of excellence for systems and services of intelligent transport II., ITMS 
26220120050 supported by the Research \& Development Operational Programme funded by the ERDF.

Institutional project of Department of Road and Urban Transport, University of Žilina, Znižovanie odporu vzduchu cestných vozidiel a jeho vplyv na životné prostredie (Decreasing the aerodynamical drag of road vehicles and its influence on environment), 7/KCMD/2017.

\section{REFERENCES}

1. Babin M., Buda M. and Majercak J. Terminals for transportation of dangerous goods. Transport means 2012 : proceedings of the 16th international conference : October 25-26, 2012, Kaunas University of Technology, Lithuania, 2012, 166-170.

2. Bukova B., Brumercikova E. and Kondek P. Determinants of the EU transport market. ESM 2016 : the 2016 international conference on Engineering science and management : proceedings : August 1314, 2016 Zhengzhou, Henan, China, 2016, 249-252.

3. Caban J. et al. Studies on operational wear of glycol-based brake fluid. Przemysl Chemiczny. vol. 94, 10/2015, 1802-1806.

4. Camaj J., Lalinska J. and Masek J. Simulations of continental logistics center from the perspective of technologist. International conference on information, management science and application (ICIMSA) : 28-30 October 2014, Beijing, China. 305-308.

5. Deur J., Skugor B. and Cipek M. Integration of Electric Vehicles into Energy and Transport Systems. Automatika, vol. 56, 4/2015, 395-410.

6. Drozdziel P., Rybicka I., Madlenak R., Andrusiuk A. and Siluch D. The engine set damage assessment in the public transport vehicles. Advances in Science and Technology Research Journal, vol. 11, 1/2017, 117-127.

7. Gasparik J., Luptak V. and Mesko P. New methodology for assessing transport connections depending on the integrated transport network. ICTTE $2016=$ international conference on Traffic and transport engineering : November 24-25, 2016, Belgrade, Serbia, 2016, 388-392.

8. Hausberger S., Rexeis M., Blassnegger J. and Silberholz G. Evaluation of fuel efficiency improvements in the Heavy-Duty Vehicle (HDV) sector from improved trailer and tire designs by application of a new test procedure. TU Graz, Graz, 2011.

9. Hudak M. and Madlenak R. The research of driver's gaze at the traffic signs. Innovations in science and education: CBU international conference proceedings, 4/2016, March 23-25, 2016, Prague, Czech Republic, 896-899.
10. Jazar R. Vehicle Dynamics, Theory and applications. Springer Science + Bussines Media, 2009.

11. Kalasova A., Cernicky L. and Hamar M. A new approach to road safety in Slovakia. Transport Systems Telematics: 12th international conference on Transport systems telematics, TST 2012, Katowice - Ustroń, Poland, October 10-13, 2012, 388-395.

12. Kampf R., Stopka O., Bartuska L. and Zeman K. Circulation of vehicles as an important parameter of public transport efficiency. Transport Means - Proceedings of the 19th International Scientific Conference on Transport Means. Kaunas (Lithuania): Kaunas University of Technology, 2015, 143-146.

13. Knez M., Jereb B. and Obrecht M. Factors Influencing the Purchasing Decisions of Low Emission Cars: A Study of Slovenia. Transportation Research, Part D, Transport and Environment, 30/2014, 53-61.

14. Knez M., Muneer T., Jereb B. and Cullinane K. The estimation of a driving cycle for Celje and a comparison to other European cities. Sustainable cities and society, vol. 11, 2/2014, 56-60.

15. Kucera L., Gajdac I. and Mruzek M. Simulation of parameters influencing the electric vehicle range. Communications - scientific letters of UNIZA, vol. $18,1 \mathrm{~A} / 2016,59-63$.

16. Lopez E., Monzon A. and Pfaffenbichler P. C. Assessment of energy efficiency and sustainability scenarios in the transport system. European Transport Research Review, vol. 4, 1/2012, 47-56.

17. Matuszak Z., Jaskiewicz M., Ludwinek K. and Gawecki Z. Special characteristics of reliability for serial mechatronic systems, Selected Problems of Electrical Engineering and Electronics WZEE'2015, Kielce, Poland, 2015.

18. Mruzek M., Gajdac I., Kucera L. and Barta D. Analysis of parameters influencing electric vehicle range. Procedia Engineering, 134/2016, 165-174.

19. Nadolski R., Ludwinek K., Staszak J. and Jaskiewicz M. Utilization of BLDC Motor In Electrical Vehicles, Przegląd Elektrotechniczny (Electrical Review), 2012.

20. Ondrus J. and Hockicko P. Braking deceleration measurement using the video analysis of motions by $\mathrm{Sw}$ tracker. Transport and telecommunication, vol. 16, 2/2015, 127-137.

21. Rajamani R. Vehicle dynamics and control. Springer, New York, 2012.

22. Rievaj V. et al. The impact of air resistance on the fuel consumption in real conditions within the transport operation. Communications - scientific letters of UNIZA, vol. 18, 2/2016, 57-61.

23. Skrucany T., Sarkan B. and Gnap J. Influence of Aerodynamic Trailer Devices on Dragreduction Measured in a Wind Tunnel. Eksploatacja i nieza- 
wodnosc - Maintenance and reliability, vol. 18, 1/2016, 151-154.

24. Standard STN 30 0554. Road motor vehicles. Coastdown test of road motor vehicles. (Slovakia).

25. Stoilova S. and Kunchev L. Application of the graph theory, AHP method and Cost Benefits Analysis for route selection of a road train. J Balk Tribol Assoc, vol. 22, 2/2016, 1041-1056.

26. Van der Krieke J. and Van Raemdonck G. Analyzing Fuel Savings of an Aerodynamic Drag Reduc- tion Device with the Aid of a Robust Linear Least Squares Method. SAE Int. J. Commer, vol. 7, 2/2014, 675-684.

27. Zvolensky P., Pultznerova A. and Grencik J. The simulation calculation of acoustics energy transfer through the material structure. MATEC web of conferences: 5th international scientific conference "Integration, Partnership and Innovation in Construction Science and Education", vol. 86, 2016, article num. 04001. 